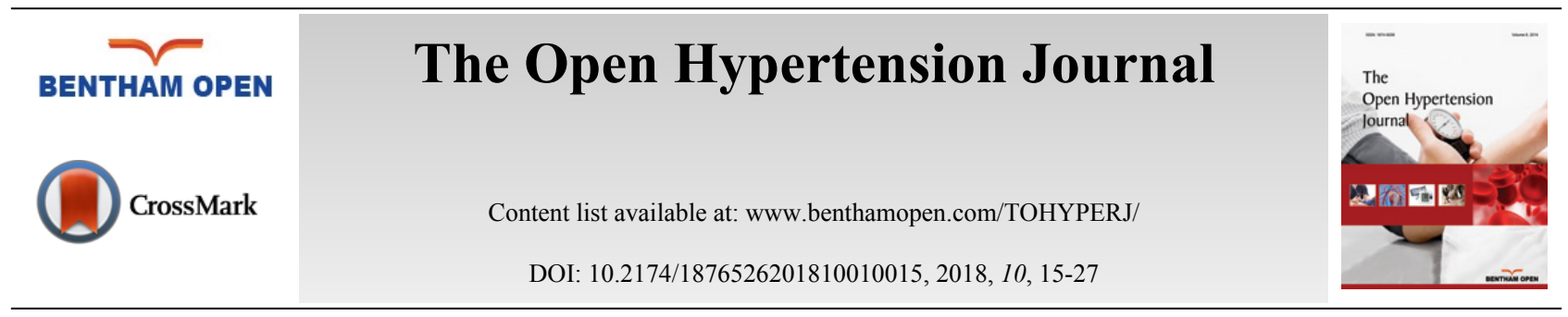

RESEARCH ARTICLE

\title{
Determinants of Blood Pressure Control and Prevalence of Hypertension in Adults in 2017: A Population-Based Study in West Jakarta
}

\author{
Lucky Aziza Bawazir $^{1, *}$ and Wicensius P.H. Sianipar ${ }^{2}$ \\ ${ }^{I}$ Department of Internal Medicine, Faculty of Medicine Universitas Indonesia - Cipto Mangunkusumo National \\ Teaching Hospital, Jakarta 10430, Indonesia \\ ${ }^{2}$ Tegal Alur II Community Health Center, Jakarta 11840, Indonesia
}

Received: July 13, 2018

Revised: August 15, 2018

Accepted: August 28, 2018

\begin{abstract}
:
Background:

The high prevalence of hypertension in developing countries underlines the need for accurate data on the prevalence of adult hypertension, as well as patient characteristics and determinants of blood pressure control. As this information is currently not available, our aim was to collect such data from a population of patients in the Tegal Alur Administrative Village, West Jakarta Indonesia.
\end{abstract}

\section{Objective:}

We conducted a case-control study $(\mathrm{n}=152)$ to identify determinants of hypertension and a cross-sectional study $(\mathrm{n}=3842)$ to determine hypertension prevalence and investigate determinants of blood pressure control in hypertensive adults $(\geq 18$ years old).

\section{Methods:}

The cross-sectional design involved the diagnosis of hypertension via home visits (active detection) and routine clinical examinations at the Tegal Alur II Community Health Center (passive detection). In the case-control design, the groups were sex-matched.

\section{Results:}

In 2017, the prevalence of hypertension in adults in Tegal Alur was 16.8\% $(\mathrm{n}=646)$, and the rate of uncontrolled hypertension was $89 \%(\mathrm{n}=572)$. A multivariate analysis showed that the adjusted prevalence ratio for comorbidities was $2.1(95 \%$ confidence interval [CI]: $1.48-3.12 ; p=0.005)$. A body mass index indicative of being overweight $\left(\geq 23 \mathrm{~kg} / \mathrm{m}^{2}\right)$ had an odds ratio of $2.25(95 \% \mathrm{CI}$ : $1.14-4.44 ; p=0.016)$.

\section{Conclusion:}

Comorbidities were the strongest predictor of uncontrolled blood pressure in hypertensive adults of Tegal Alur. Being overweight (BMI $\geq 23 \mathrm{~kg} / \mathrm{m}^{2}$ ) was significantly associated with hypertension.

Keywords: Determinants, Blood pressure control, Prevalence of hypertension, Population-based study, West Jakarta, Indonesia.

\section{INTRODUCTION}

In 2008, approximately $40 \%$ of individuals worldwide over the age of 25 years were diagnosed with hypertension

\footnotetext{
* Address correspondence to this author at the Department of Internal Medicine, Faculty of Medicine Universitas Indonesia - Cipto Mangunkusumo National Teaching Hospital, Jalan Sutan Syahrir 6, Menteng, 10430 Jakarta Pusat, Indonesia; Tel: +628158017000; Fax: +62213100762; E-mail: tyasretno77@yahoo.co.id
} 
[1]. In the Southeast Asia region, 35\% of adults were diagnosed with hypertension and $9.4 \%$ of all deaths were related to hypertension [2]. In 2013, the prevalence of hypertension in adults in Indonesia was reported to be $26.5 \%$ based on the National Health Survey conducted by Indonesia's Ministry of Health [3]. In Jakarta, the capital city of Indonesia, the prevalence of hypertension in adults was $20 \%$ [3]. In low-income countries, half of the patients with hypertension are not aware of the methods to control their blood pressure [4]. Uncontrolled blood pressure contributes to cardiovascular and cerebrovascular disease. In 2013, the World Health Organization (WHO) reported that hypertension accounted for $45 \%$ of cardiovascular-related deaths and $51 \%$ of stroke-related deaths [1].

There are known risk factors for hypertension such as high-fat, high-salt diets, low dietary intake of vegetables and fruits, being overweight, obesity, excessive alcohol consumption, physical inactivity, age, genetic factors, psychological stressors, and socioeconomic factors [4]. A study by Rahajeng [5] showed that biological factors, such as age, male sex, overall obesity, and abdominal obesity were significantly associated with hypertension in adults. With regard to psychosocial factors, a study by $\mathrm{Xu}$ [6] and Carvalho [7] showed that there was a significant association between hypertension and quality of life. Furthermore, a study by Cois [8] showed that there was a significant association between socioeconomic status (income bracket and education) and blood pressure in adults.

Currently, there is no population-based study available in Indonesia that has obtained data on the determinants of blood pressure control and the prevalence of hypertension in adults, specifically in areas comprising low socioeconomic populations like Tegal Alur Administrative Village. A previous study in Indonesia by Hussain [9] showed that there was a significant association between blood pressure control and abdominal circumference, but the subjects of that study were limited to adults aged $\geq 40$ years. The effects of medication adherence, quality of life, and other determinants of blood pressure control in hypertensive adults of Jakarta remain unknown.

Owing to the high prevalence of hypertension in developing countries such as Indonesia, there is a need for accurate data regarding the annual prevalence of hypertension in adults, as well as knowledge of patient characteristics and determinants of blood pressure control in hypertensive adults. This study aimed to gain an accurate understanding of the characteristics of hypertensive adults in areas with low socioeconomic status.

\section{MATERIAL AND METHODS}

\subsection{Study Designs}

This study used two study designs: cross-sectional and case-control. The objective of the cross-sectional design was to determine the prevalence of hypertension and to identify determinants of blood pressure control as well as the characteristics of hypertensive adults in the Tegal Alur Administrative Village in 2017. The objective of the casecontrol design was to determine the relationship between risk factors (physical activity, smoking, comorbidities, and Body Mass Index [BMI]) and the prevalence of hypertension in adults in the Tegal Alur Administrative Village. The subjects in the case-control design were also interviewed to identify the differences in quality of life between hypertensive and normotensive adults.

\subsection{Time and Location of the Study}

The Tegal Alur II Community Health Center is located in the Tegal Alur Administrative Village, Kalideres Subdistrict, West Jakarta. The working area of Tegal Alur II Community Health Center consists of six neighborhoods: RW 04, RW 05, RW 10, RW 11, RW 15, and RW 16. Home visits to RW 04, RW 05, and RW 15 were conducted in 2017 by staff members of the Tegal Alur II Community Health Center. Secondary data from home visit reports (active detection) and routine clinical visits for 2017 (passive detection), including interviews and BMI measurements, were obtained from January to February 2018.

\subsection{Sampling Methods}

In the cross-sectional design, we used a total sampling approach for citizens residing in the RW 04, RW 05, and RW 15 neighborhoods. We included adult patients aged $\geq 18$ years. The estimated minimum sample size required to obtain the prevalence of hypertension in our study population was 61.4 (rounded to 62). This number was based on the prevalence of hypertension in Jakarta in 2013, which was 20\% [3], a 10\% margin of error, and a critical value of 1.96. To identify blood pressure control determinants, we estimated that the minimum sample size required would be 571 , assuming a standard effect of 0.8, based on a study by Menanga [10], and critical values of 1.96 and 0.84 .

In the case-control design, a consecutive sampling approach was used for patients visiting the Community Health 
Center. We included subjects aged $\geq 40$ years and the groups were sex-matched. The minimum sample size needed to identify determinants of the prevalence of hypertension was 152, assuming an expected odds ratio (OR) of 2 and critical values of 1.96 and 0.84 .

\subsection{Procedures and Instruments}

Home visits (active detection) were conducted in 2017. All blood pressure measurements were taken by trained Tegal Alur II Community Health Center staff members using the patient's right arm. Routine clinical visits (passive detection) of the hypertensive patients in 2017 were documented in their medical records. All hypertensive patients living in the RW 04, RW 05, and RW 15 neighborhoods were included in the study. The authors screened medical records for duplicate information, as some of the hypertensive patients were also examined in home visits.

In the case-control design, all patients who fulfilled the inclusion criteria were interviewed. Before the interviews, the patient's height and weight measurements were taken using a mechanical beam scale with a height rod. The measurements were performed by trained staff blinded to the study participants. Quality of life data of the patients were measured using the Health-Related Quality of Life Short Form-36 (HRQoLSF-36) which is a validated questionnaire containing 36 items with both physical and mental components.

\subsection{Covariates}

In the cross-sectional design, the following variables were considered to be risk factors for blood pressure control: sex, age, highest educational level achieved, income bracket, medication adherence, comorbidities, and the setting/location where hypertension was first diagnosed/detected. The patients were divided into three categories according to age: $\leq 49$ years, 50-59 years, and $\geq 60$ years. The categories of the highest educational level achieved comprised the following: Illiterate, elementary school, junior high school, senior high school, and college. Monthly income brackets were categorized based on the Provincial Monthly Wage (PMW) of Jakarta in 2017. The standard PMW was Rp 3,335,750. The income bracket categories included the following: below PMW, at PMW, and above PMW. Medication adherence categories comprised adherence and non-adherence. At our Community Health Center, antihypertensive agents were given for one week to all patients, based on the guidelines of Indonesia's National Health Insurance. Therefore, patients were considered adherent to the treatment regimen if they received the antihypertensive prescriptions from the physicians once a week, which was recorded in the medical records. Due to the low frequencies, the comorbidities were divided into two categories: Comorbidities (diabetes mellitus, cardiovascular disease, and cerebrovascular disease) and no comorbidities. The detection of hypertension was dependent on the location where the patient was first diagnosed and was divided into two categories: Community Health Center (passive detection) and home visit (active detection).

In case-control design, the following variables were considered to be risk factors for hypertension: Physical activity, smoking habits, comorbidities, and BMI. The physical activity categories comprised physically active and physically inactive. The criteria for physical activity included aerobic activity (running, walking, or cycling) performed three to four times a week for at least 30 minutes in each episode. Smoking habits were divided into two categories: smokers and non-smokers. The comorbidities were categorized into two groups: Comorbidities (presence of a history of diabetes mellitus, cardiovascular disease, and cerebrovascular disease) and no comorbidities (absent). Two categories of BMI were used in this study: Normoweight $\left(\mathrm{BMI}<23 \mathrm{~kg} / \mathrm{m}^{2}\right)$ and overweight $\left(\mathrm{BMI} \geq 23 \mathrm{~kg} / \mathrm{m}^{2}\right)$.

\subsection{Outcomes}

In the cross-sectional design, the clinical outcomes were controlled blood pressure or uncontrolled blood pressure. To assess the patient's blood pressure control, the mean blood pressure measurements of three recent visits were obtained from the Community Health Center's medical records. During the home visits, the mean blood pressure of two measurements with a 5-minute interval was obtained to assess the patient's blood pressure control. The patient's selfreported history of uncontrolled blood pressure was also taken in both settings and included in the medical records and the home visit reports. In the case-control design, the groups were divided into hypertensive and normotensive groups. We adhered to the Joint National Committee (JNC) 2003 criterion for hypertension [11], which was defined as elevated blood pressure of $\geq 140 / 90 \mathrm{mmHg}$. Patients with blood pressure $<140 / 90 \mathrm{mmHg}$ were stratified into the controlled blood pressure (in the cross-sectional design) and normotensive (in the case-control design) groups. For patients with comorbidities, a blood pressure of $<130 / 80 \mathrm{mmHg}$ was defined as controlled blood pressure. 


\subsection{Data Analysis}

For both the study designs, sociodemographic data are presented as frequencies and proportions. Numerical data are presented as means and standard deviations $( \pm \mathrm{SD})$. In the cross-sectional design, chi-square test was used in the bivariate analyses of patients' characteristics (sex, age, highest educational level achieved, income bracket, medication adherence, comorbidities, and location/setting of hypertension detection/diagnosis) and blood pressure control. A post hoc bivariate analysis was performed for covariates with more than two categories. In the bivariate analysis, prevalence Ratios (PR), 95\% Confidence Intervals (CI), and $p$-values for each independent variable were calculated, with $p$-values $<0.05$ indicating statistical significance. An arbitrary $p$-value of $<0.25$ was used as the criterion for including a variable in the multivariate analysis with logistic regression model. In the logistic regression model, adjusted prevalence ratios for each of the relevant covariates were calculated.

In the case-control design, paired categorical tests were performed. The independent variables included physical activity, smoking habits, comorbidities, and BMI. The dependent variables included hypertensive and normotensive status. The dimensions associated with quality of life were as follows: Physical Functioning (PF), role limitations due to physical health (RP), role limitations due to emotional problems (RE), Energy/Fatigue (EF), Emotional Well-Being (EWB), Social Functioning (SF), Pain (P), and General Health (GH). These dimensions are presented as means ( \pm SDs). We performed a linear regression analysis in the hypertensive group to compare the characteristics of the patients as covariates and the quality of life dimensions as outcomes. The data analysis was performed using SPSS Statistics software version 20.0 (IBM Corp., Armonk, NY, USA).

\section{RESULTS}

\subsection{Prevalence of Hypertension}

In this study, 646 of 3842 patients living in the RW 04, RW 05, and RW 15 neighborhoods were diagnosed with hypertension. Thus, in 2017, the prevalence of hypertension in adults in the Tegal Alur Administrative Village was $16.8 \%$.

\subsection{Characteristics of Hypertensive Patients in the Cross-sectional Study Design}

The mean age of the hypertensive patients was $53.05( \pm 10.91)$ years, and the mean systolic and diastolic blood pressures were $149.69( \pm 17.64) \mathrm{mmHg}$ and $87.31( \pm 9.29) \mathrm{mmHg}$, respectively. The mean time since the diagnosis of hypertension was $2.08( \pm 4.25)$ years.

Table 1 summarizes the characteristics of the hypertensive patients in the cross-sectional study design.

Table 1. Characteristics of hypertensive adults in Tegal Alur Administrative Village $(n=646)$.

\begin{tabular}{|c|c|c|}
\hline Variables & Number & $\begin{array}{c}\text { Percentage } \\
(\%)\end{array}$ \\
\hline \multicolumn{3}{|l|}{$\operatorname{sex}$} \\
\hline Men & 190 & $29.4 \%$ \\
\hline Women & 456 & $70.6 \%$ \\
\hline \multicolumn{3}{|l|}{ Age } \\
\hline$\leq 49$ years old & 249 & $38.5 \%$ \\
\hline 50-59 years old & 225 & $34.8 \%$ \\
\hline$\geq 60$ years old & 172 & $26.6 \%$ \\
\hline \multicolumn{3}{|l|}{ Highest educational level achieved } \\
\hline Illiterate & 9 & $1.4 \%$ \\
\hline Elementary school & 337 & $52.2 \%$ \\
\hline Junior high school & 124 & $19.2 \%$ \\
\hline Senior high school & 162 & $25.1 \%$ \\
\hline College & 14 & $2.2 \%$ \\
\hline \multicolumn{3}{|l|}{ Monthly income } \\
\hline Below PMW $(<\operatorname{Rp} 3,335,750)$ & 482 & $74.6 \%$ \\
\hline PMW (Rp 3,335,750) & 23 & $3.6 \%$ \\
\hline Above PMW (>Rp 3,335,750) & 141 & $21.8 \%$ \\
\hline Comorbidities & & \\
\hline
\end{tabular}


(Table 1) contd.....

\begin{tabular}{|c|c|c|}
\hline Variables & Number & $\begin{array}{c}\text { Percentage } \\
(\%)\end{array}$ \\
\hline \multicolumn{3}{|l|}{$\operatorname{sex}$} \\
\hline Present & 28 & $4.3 \%$ \\
\hline Absent & 618 & $95.7 \%$ \\
\hline \multicolumn{3}{|l|}{ Medication adherence } \\
\hline Non-adherent & 357 & $55.3 \%$ \\
\hline Adherent & 289 & $44.7 \%$ \\
\hline \multicolumn{3}{|l|}{ Place of hypertension detection } \\
\hline Community Health Center & 157 & $24.3 \%$ \\
\hline Home visit & 489 & $75.7 \%$ \\
\hline
\end{tabular}

Of the 646 hypertensive patients, $70.6 \%(n=456)$ were women. The majority of patients belonged to the age category $\leq 49$ years, representing $38.5 \%$ of all hypertensive patients $(n=249)$. For slightly over half $(52.2 \%)$ of the hypertensive patients, the highest educational level achieved was elementary school. The majority of the patients belonged to the below PMW (74.6\%) monthly income bracket and did not have any comorbidities (95.7\%). Over half $(55.3 \%)$ of the hypertensive patients were non-adherent and the majority was diagnosed with hypertension during a home visit (75.7\%).

\subsection{Blood Pressure Control}

Of the 646 hypertensive subjects, $89 \%$ had uncontrolled blood pressure (systolic blood pressure of $\geq 140 \mathrm{mmHg}$ in hypertensive subjects without comorbidities and $\geq 130 \mathrm{mmHg}$ in hypertensive subjects with comorbidities).

\subsection{Determinants of Blood Pressure Control}

Table 2 illustrates the results of the bivariate analysis of blood pressure control determinants in hypertensive subjects.

Table 2. Bivariate analysis of determinants of blood pressure control in hypertensive adults from the Tegal Alur Administrative Village.

\begin{tabular}{|c|c|c|c|c|}
\hline Variables & $\begin{array}{c}\text { Uncontrolled blood pressure } \\
\text { n (\%) }\end{array}$ & $\begin{array}{c}\text { Controlled blood pressure } \\
\text { n (\%) }\end{array}$ & $P$-value & Prevalence ratio $(95 \% \mathrm{CI})$ \\
\hline \multicolumn{5}{|l|}{ Sex } \\
\hline Male & $172(30.1 \%)$ & $18(24.3 \%)$ & 0.307 & $0.96(0.91-1.02)$ \\
\hline Female & $400(69.9 \%)$ & $56(75.7 \%)$ & & \\
\hline \multicolumn{5}{|l|}{ Age } \\
\hline$\leq 49$ years & $226(39.5 \%)$ & $23(31.1 \%)$ & & \\
\hline $50-59$ years & $193(33.7 \%)$ & $32(43.2 \%)$ & 0.091 & $0.94(0.88-1.01)$ \\
\hline$\geq 60$ years & $153(26.7 \%)$ & $19(25.7 \%)$ & 0.543 & $0.98(0.91-1.04)$ \\
\hline \multicolumn{5}{|l|}{ Level of education } \\
\hline Illiterate & $7(1.2 \%)$ & $2(2.7 \%)$ & 0.538 & $0.83(0.57-1.22)$ \\
\hline Elementary school & $298(52.1 \%)$ & $39(52.7 \%)$ & 1.0 & $0.95(0.81-1.10)$ \\
\hline Junior high school & $106(18.5 \%)$ & $18(24.3 \%)$ & 0.692 & $0.92(0.78-1.08)$ \\
\hline Senior high school & $148(25.9 \%)$ & $14(18.9 \%)$ & 1.0 & $0.98(0.84-1.14)$ \\
\hline College & $13(2.3 \%)$ & $1(1.4 \%)$ & & \\
\hline \multicolumn{5}{|l|}{ Monthly income } \\
\hline Below PMW $(<\operatorname{Rp} 3,335,750)$ & $434(75.9 \%)$ & $48(64.9 \%)$ & 0.168 & $1.04(0.97-1.12)$ \\
\hline PMW (Rp 3,335,750) & $17(3.0 \%)$ & $6(8.1 \%)$ & 0.213 & $0.86(0.67-1.10)$ \\
\hline Above PMW (>Rp 3,335,750) & $121(21.2 \%)$ & $20(27.0 \%)$ & & \\
\hline \multicolumn{5}{|l|}{ Comorbidities } \\
\hline Present & $18(3.1 \%)$ & $10(13.5 \%)$ & 0.001 & $0.71(0.54-0.94)$ \\
\hline Absent & $554(96.9 \%)$ & $64(86.5 \%)$ & & \\
\hline \multicolumn{5}{|l|}{ Medication adherence } \\
\hline Non-adherent & $351(61.4 \%)$ & $6(8.1 \%)$ & $<0.001$ & $1.28(1.20-1.37)$ \\
\hline Adherent & $221(38.6 \%)$ & $68(91.9 \%)$ & & \\
\hline Place of hypertension detection & & & & \\
\hline
\end{tabular}


(Table 2) contd.....

\begin{tabular}{|l|c|c|c|c|}
\hline \multicolumn{1}{|c|}{ Variables } & $\begin{array}{c}\text { Uncontrolled blood pressure } \\
\text { n (\%) }\end{array}$ & $\begin{array}{c}\text { Controlled blood pressure } \\
\text { n (\%) }\end{array}$ & P-value & Prevalence ratio (95\% CI) \\
\hline Home visit & $460(80.4 \%)$ & $29(60.8 \%)$ & $<\mathbf{0 . 0 0 1}$ & $\mathbf{1 . 3 1}(\mathbf{1 . 1 9}-\mathbf{1 . 4 6 )}$ \\
\hline Community health Center & $112(19.6 \%)$ & $45(39.2 \%)$ & - & - \\
\hline
\end{tabular}

The following variables were not significantly associated with uncontrolled blood pressure $(p>0.05)$ : Sex, age, highest educational level achieved, and monthly income bracket. Comorbidities were significantly associated with uncontrolled blood pressure with a $p$-value of 0.001 (PR: $0.71 ; 95 \% \mathrm{CI}$ : 0.54-0.94).

Non-adherence with physician's prescriptions was significantly associated with uncontrolled blood pressure ( $p$ $<0.001)$. The proportion of adherent patients with uncontrolled blood pressure $(38.6 \%)$ was lower than the proportion of non-adherent patients with uncontrolled blood pressure (61.4\%). Hypertensive subjects who were non-adherent had 1.28-fold higher risk of uncontrolled blood pressure than hypertensive subjects who were adherent (PR: $1.28 ; 95 \%$ CI: $1.20-1.37)$.

The location/setting where hypertension was diagnosed was significantly associated with uncontrolled blood pressure $(p<0.001)$. The proportion of patients with uncontrolled blood pressure whose diagnoses resulted from home visits $(80.4 \%)$ was higher than that of patients whose diagnoses were detected at the Community Health Center (19.6\%). Hypertensive patients diagnosed during home visits had a 1.31-fold higher risk of having uncontrolled blood pressure than those diagnosed at the Community Health Center (PR: 1.31; 95\% CI: 1.19-1.46). Results of the multivariate analysis with logistic regression model are shown in Table $\mathbf{3}$.

Table 3. Multivariate analysis of determinants associated with blood pressure control.

\begin{tabular}{|c|c|c|c|c|c|c|c|c|}
\hline- & \multirow{2}{*}{ Coefficient } & \multirow{2}{*}{ S.E. } & \multirow{2}{*}{ Wald } & \multirow{2}{*}{ Df } & \multirow{2}{*}{$\boldsymbol{*}$ P-value } & \multirow{2}{*}{ Adjusted PR } & \multicolumn{2}{|c|}{ 95\% CI } \\
\cline { 7 - 10 } & & & & & & & $\min$ & $\max$ \\
\hline Comorbidities & 1.287 & 0.459 & 7.845 & 1 & 0.005 & 2.1 & 1.48 & 3.12 \\
\hline Non-adherence & -2.337 & 0.479 & 23.827 & 1 & $<0.001$ & 0.11 & 0.03 & 0.36 \\
\hline Home visit & -0.886 & 0.318 & 7.765 & 1 & 0.005 & 0.46 & 0.24 & 0.86 \\
\hline Income $<$ PMW & 0.041 & 0.322 & 0.016 & 1 & 0.899 & 1.03 & 0.94 & 1.07 \\
\hline
\end{tabular}

Based on the logistic regression model, the presence of comorbidities was the strongest predictor of uncontrolled blood pressure in the Tegal Alur Administrative Village (adjusted PR: 2.1; 95\% CI: 1.48-3.12).

\subsection{Characteristics of Subjects in the Case-control Study Design}

Table 4 summarizes the patient characteristics in the case-control study design.

Table 4. Characteristics of patients in the hypertensive and normotensive groups.

\begin{tabular}{|c|c|c|c|}
\hline Variable & $\begin{array}{l}\text { Hypertensive group } \\
\mathrm{N}=76 \\
\end{array}$ & $\begin{array}{c}\text { Normotensive group } \\
\qquad N=76 \\
\end{array}$ & $P$-value \\
\hline $\begin{array}{l}\text { Systolic pressure, } \mathrm{mmHg} \\
\text { mean }( \pm \mathrm{SD}), \mathrm{n}(\%)\end{array}$ & $134.13( \pm 21.0)$ & $107.58( \pm 12.42)$ & $<\mathbf{0 . 0 0 1}$ \\
\hline Diastolic pressure, $\mathrm{mmHg}$, mean $( \pm \mathrm{SD}), \mathrm{n}(\%)$ & $81.71( \pm 10.11)$ & $71.32( \pm 16.0)$ & $<0.001$ \\
\hline \multicolumn{4}{|l|}{ Sex, n (\%) } \\
\hline Male & $22(28.9 \%)$ & $21(27.6 \%)$ & 0.157 \\
\hline Female & $54(71.1 \%)$ & $55(72.4 \%)$ & \\
\hline \multicolumn{4}{|l|}{ Age, years, } \\
\hline mean $( \pm \mathrm{SD}), \mathrm{n}(\%)$ & $55.13( \pm 10.37)$ & $48.82( \pm 8.79)$ & $<0.001$ \\
\hline$\leq 49$ years & $21(27.6 \%)$ & $43(56.6 \%)$ & \\
\hline $50-59$ years & $52(68.4 \%)$ & $32(42.1 \%)$ & \\
\hline$\geq 60$ years & $3(3.9 \%)$ & $1(1.3 \%)$ & \\
\hline \multicolumn{4}{|l|}{ Level of education, $n(\%)$} \\
\hline Illiterate & $10(13.2 \%)$ & $3(3.9 \%)$ & 0.002 \\
\hline Elementary school & $35(46.1 \%)$ & $32(42.1 \%)$ & \\
\hline Junior high school & $19(25 \%)$ & $16(21.1 \%)$ & \\
\hline Senior high school & $12(15.8 \%)$ & $25(32.9 \%)$ & \\
\hline \multicolumn{4}{|l|}{ Marital status, n (\%) } \\
\hline Married & $64(84.2 \%)$ & $67(88.2 \%)$ & 0.011 \\
\hline
\end{tabular}


(Table 4) contd.....

\begin{tabular}{|c|c|c|c|}
\hline Variable & $\begin{array}{l}\text { Hypertensive group } \\
\qquad N=76\end{array}$ & $\begin{array}{c}\text { Normotensive group } \\
\qquad N=76\end{array}$ & $P$-value \\
\hline Single & $12(15.8 \%)$ & $9(11.8 \%)$ & \\
\hline \multicolumn{4}{|l|}{ Monthly income, n (\%) } \\
\hline Below PMW $(<\operatorname{Rp} 3,335,750)$ & $73(96.1 \%)$ & $58(76.3 \%)$ & $<0.001$ \\
\hline PMR (Rp 3,335,750) & $3(3.9 \%)$ & $12(15.8 \%)$ & \\
\hline Above PMW (>Rp 3,335,750) & $0(0 \%)$ & $6(7.9 \%)$ & \\
\hline \multicolumn{4}{|l|}{ Physical activity, n (\%) } \\
\hline Yes & $29(38.2 \%)$ & $29(38.2 \%)$ & 1.0 \\
\hline No & $47(61.8 \%)$ & $47(61.8 \%)$ & \\
\hline \multicolumn{4}{|l|}{ Smoking status, n (\%) } \\
\hline Smoker & $10(13.2 \%)$ & $14(18.4 \%)$ & 0.285 \\
\hline Non-smoker & $66(86.8 \%)$ & $62(81.6 \%)$ & \\
\hline \multicolumn{4}{|l|}{ Comorbidities } \\
\hline Present & $9(11.8 \%)$ & $5(6.6 \%)$ & 0.25 \\
\hline Absent & $67(88.2 \%)$ & $71(93.4 \%)$ & \\
\hline \multicolumn{4}{|l|}{ Body mass index, $\mathrm{kg} / \mathrm{m}^{2}, \mathrm{n}(\%)$} \\
\hline Mean (SD) & $25.55(3.97)$ & $23.67(3.97)$ & 0.003 \\
\hline Overweight $\left(\geq 23 \mathrm{~kg} / \mathrm{m}^{2}\right)$ & $57(75 \%)$ & $42(55.3 \%)$ & See Table $\mathbf{5}$ \\
\hline Normoweight $\left(<23 \mathrm{~kg} / \mathrm{m}^{2}\right)$ & $19(25 \%)$ & $34(44.7 \%)$ & \\
\hline
\end{tabular}

The mean $( \pm \mathrm{SD})$ systolic and diastolic blood pressures in the hypertensive group $(134.13[ \pm 21.0] \mathrm{mmHg}$ and 81.71 $[ \pm 10.11] \mathrm{mmHg}$, respectively) were higher than the mean $( \pm \mathrm{SD})$ systolic and diastolic blood pressures in the normotensive group $(107.58[ \pm 12.42] \mathrm{mmHg}$ and $71.32[ \pm 16.0] \mathrm{mmHg}$, respectively). There was no significant difference in blood pressure between the sexes in both groups $(p=0.157)$ as the patients were sex-matched. The mean $( \pm \mathrm{SD})$ age in the hypertensive group (55.13 $[ \pm 10.37]$ years) was higher than in the normotensive group (48.82 [ \pm 8.79$]$ years). The majority of the patients in the hypertensive and normotensive groups were married $(84.2 \%$ and $88.2 \%$, respectively). Over half of the patients in the hypertensive and normotensive groups had monthly incomes below the PMW (96.1\% and $76.3 \%$, respectively). The mean $( \pm \mathrm{SD}) \mathrm{BMI}$ in the hypertensive group $\left(25.55[ \pm 3.97] \mathrm{kg} / \mathrm{m}^{2}\right)$ was higher than that in the normotensive group $\left(23.67[ \pm 3.97] \mathrm{kg} / \mathrm{m}^{2}\right)$.

\subsection{Determinants of Hypertension}

There was no significant association between physical activity $(p=1.0)$, smoking $(p=0.285)$, or comorbidities $(p=$ $0.25)$ and hypertension.

The results of the bivariate analysis between BMI and hypertension are shown in Table 5. As for the other covariates believed to be associated with hypertension (physical activity, smoking, and comorbidities), the association between BMI and hypertension was tested using the McNemar test.

Table 5. Bivariate analysis between body mass index and hypertension.

\begin{tabular}{|c|c|c|c|c|c|}
\hline & - & \multicolumn{2}{|c|}{ Normotensive (Control) } & - & - \\
\hline \multirow{2}{*}{-} & - & $\begin{array}{c}\text { Overweight }\left(\geq \mathbf{2 3} \mathbf{~ k g} / \mathbf{m}^{2}\right) \\
\mathbf{n}(\mathbf{\%})\end{array}$ & $\begin{array}{c}\text { Normoweight }\left(<\mathbf{2 3} \mathbf{~ k g} / \mathbf{m}^{2}\right) \\
\mathbf{n}(\mathbf{\%})\end{array}$ & $\boldsymbol{P}$-value & OR (95\% CI) \\
\hline \multirow{2}{*}{ Hypertensive (Case) } & Overweight $\left(\geq 23 \mathrm{~kg} / \mathrm{m}^{2}\right)$ & $30(19.6 \%)$ & $27(17.6 \%)$ & \multirow{2}{*}{$\mathbf{0 . 0 1 6}$} & $\mathbf{2 . 2 5}(\mathbf{1 . 1 4}-\mathbf{4 . 4 4})$ \\
\cline { 2 - 5 } & Normoweight $\left(<23 \mathrm{~kg} / \mathrm{m}^{2}\right)$ & $12(7.8 \%)$ & $7(4.6 \%)$ & \\
\hline
\end{tabular}

In the bivariate analysis, hypertension was significantly associated with BMI ( $p=0.016$; OR: $2.25 ; 95 \%$ CI: 1.14-4.44). A multivariate analysis was not performed as the other covariates (physical activity, smoking, and comorbidities) did not fulfill the arbitrary $p$-value of $<0.25$.

\subsection{Quality of Life}

Table 6 reports the mean differences in each dimension between hypertensive and normotensive groups. 
Table 6. Quality of life of hypertensive and normotensive groups.

\begin{tabular}{|c|c|c|c|c|c|}
\hline \multirow{2}{*}{ Dimension } & \multicolumn{2}{|c|}{ Hypertensive Group } & \multicolumn{2}{|c|}{ Normotensive Group } & \multirow{2}{*}{$\boldsymbol{P}$-value } \\
\cline { 2 - 5 } & Mean & SD & Mean & SD & $\mathbf{0 . 0 4 2}$ \\
\hline PF & 88.22 & 16.52 & 93.75 & 41.66 & 0.704 \\
\hline RP & 64.14 & 47.66 & 67.76 & 39.69 & 0.249 \\
\hline RE & 71.05 & 44.99 & 80.7 & 17.26 & 0.244 \\
\hline EF & 72.5 & 17.01 & 72.57 & 17.26 & 0.835 \\
\hline EWB & 82.51 & 16.06 & 82.75 & 12.8 & 0.949 \\
\hline SF & 94.9 & 11.57 & 94.5 & 20.78 & 0.832 \\
\hline P & 73.42 & 20.81 & 73.68 & 22.23 & 0.080 \\
\hline
\end{tabular}

PF: Physical Functioning, RP: Role limitations due to physical health, RE: Role limitations due to emotional problems, EF: Energy/Fatigue, EWB: Emotional Well-being, SF: Social Functioning, P: Pain, GH: General Health.

The only significant difference between the two groups was found in the PF dimension $(p=0.042)$. The mean PF dimension in the hypertensive group (88.22 [ \pm 16.52$])$ was lower than that in the normotensive group (93.75 [ \pm 11.66$])$.

Table 7 shows the results of the linear regression analysis to identify associations between the patient characteristics and quality of life.

Table 7. Linear regression model of the quality of life in the hypertensive and normotensive groups.

\begin{tabular}{|c|c|c|c|c|c|c|c|c|}
\hline \multirow[b]{2}{*}{ Characteristics } & \multicolumn{8}{|c|}{ Dimension } \\
\hline & $\begin{array}{c}\text { PF } \\
\text { Coeff. } \\
\beta\end{array}$ & $\begin{array}{c}\text { RP } \\
\text { Coeff. } \\
\beta\end{array}$ & $\begin{array}{c}\mathbf{R E} \\
\text { Coeff. } \\
\beta\end{array}$ & $\begin{array}{c}\text { EF } \\
\text { Coeff. } \\
\text { B }\end{array}$ & $\begin{array}{c}\text { EWB } \\
\text { Coeff. } \\
\beta\end{array}$ & $\begin{array}{c}\text { SF } \\
\text { Coeff. } \\
\beta\end{array}$ & $\begin{array}{c}P \\
\text { Coeff. } \\
\beta\end{array}$ & $\begin{array}{c}\text { GH } \\
\text { Coeff. } \\
\beta\end{array}$ \\
\hline Hypertension & $-5.32 *$ & 1.04 & -11.01 & -2.21 & 0.74 & 0.42 & 4.18 & -1.87 \\
\hline Women & 2.07 & 11.66 & -8.02 & -0.64 & -0.98 & -4.24 & 4.42 & 6.85 \\
\hline Age $\geq 60$ years & -5.16 & 11.54 & 10.92 & 0.92 & 0.49 & -3.03 & -14.04 & 2.27 \\
\hline Illiterate & 5.27 & $-29.58^{*}$ & 8.81 & 5.09 & 3.98 & 4.40 & -8.46 & -3.11 \\
\hline Single & -4.60 & $23.50^{*}$ & -5.33 & $-11.31 *$ & -7.46 & -5.31 & 6.59 & 0.89 \\
\hline Below PMW & -1.01 & -23.49 & -4.78 & -5.77 & -6.77 & -3.94 & -8.90 & -8.07 \\
\hline Inactive & -0.88 & -14.86 & $14.81^{*}$ & 0.94 & 2.88 & 1.12 & -2.27 & -5.59 \\
\hline Smoking & 2.24 & -10.0 & -9.45 & 6.92 & 4.11 & -1.13 & 3.97 & 5.89 \\
\hline Comorbidities & $-8.36^{*}$ & -1.85 & $-26.41^{*}$ & 0.66 & 0.30 & -2.92 & -3.35 & -4.32 \\
\hline Overweight & 2.26 & 6.79 & 10.64 & 2.73 & 2.25 & 2.81 & -6.55 & 3.30 \\
\hline $\mathrm{R}^{2}$ & 0.095 & 0.106 & 0.093 & 0.115 & 0.069 & 0.081 & 0.082 & 0.067 \\
\hline Adjusted $\mathrm{R}^{2}$ & 0.031 & 0.042 & 0.029 & 0.053 & 0.003 & 0.016 & 0.017 & 0.001 \\
\hline $\mathrm{F}$ & 1.487 & 1.667 & 1.445 & 1.838 & 1.044 & 1.241 & 1.255 & 1.01 \\
\hline Significance $\mathrm{F}$ & 0.150 & 0.094 & 0.167 & 0.059 & 0.410 & 0.270 & 0.262 & 0.433 \\
\hline
\end{tabular}

Coeff.: Coefficient, PF: Physical Functioning, RP: Role limitations due to physical health, RE: Role limitations due to emotional problems, EF: Energy/Fatigue, EWB: Emotional Well-Being, SF: Social Functioning, P: Pain, GH: General Health. $(*)$ indicates $p$-value $<0.05$.

In the linear regression model, hypertension was significantly associated with $\operatorname{PF}(p=0.039)$. Illiteracy had a significant association with the RP dimension $(p=0.037)$, while single marital status was significantly associated with both the RP $(p=0.035)$ and EF $(p=0.005)$ dimensions. Physical inactivity was significantly associated with the RE dimension $(p=0.043)$, while comorbidities were significantly associated with both the $\operatorname{RE}(p=0.028)$ and the PF $(p=$ 0.042) dimensions.

\section{DISCUSSION}

\subsection{Prevalence of Hypertension in the Tegal Alur Administrative Village}

In 2017, the prevalence of hypertension in adults (aged $\geq 18$ years) in the Tegal Alur Administrative Village was $16.8 \%$. This prevalence was lower than the prevalence of hypertension in Jakarta $(20 \%)$ and the national prevalence of 
hypertension in Indonesia (26.5\%) in 2013 [3]. The prevalence of hypertension in this study was also lower than the prevalence of hypertension in Indonesia (21.2\%) according to the $2014 \mathrm{WHO}$ data [4].

\subsection{Determinants of Blood Pressure Control in the Tegal Alur Administrative Village}

The proportion of patients with uncontrolled blood pressure in this study was $89 \%$, which was similar to the value of $91 \%$ reported by Hussain [9]. The percentage of patients with uncontrolled blood pressure in this study was higher than the value of $63.2 \%$ reported by Menanga et al. [10] and 49\% reported by Posnenkova et al. [12].

In this study, the proportion of hypertension identified in female patients $(70.6 \%)$ was higher than that in male patients (29.4\%). This result was similar to the results of the study by Menanga et al. [10], according to which the percentage of female patients with hypertension was $63.6 \%$. Our results were contrary to popular theories that men account for a higher proportion of the hypertensive patient population than do women [1]. Previous studies have suggested that the proportion of hypertensive men was greater than the proportion of hypertensive women until the age of 45 years, and after this age, the proportion of hypertensive women would slowly become equal to the proportion of hypertensive men $[13,14]$. The percentage of the combined age group above 50 years of age in this study was $61.5 \%$, and this majority may be the reason for the predominance of hypertensive female subjects in this study. A study by Gudmondsdottir et al. [15] suggested that decreased estrogen levels in older women could alter the hypertensive proportions due to the cardiovascular-protective properties of estrogens.

In the bivariate analysis, there was no significant association between sex and blood pressure control $(p=0.307)$. Studies by Hanus et al. [16] and Keyhani et al. [17] also showed that there was no significant difference in blood pressure control between hypertensive men and women. This result was contrary to the bivariate analysis results reported by Souza et al., [18], which indicated that hypertensive female patients had better blood pressure control compared with hypertensive male patients. However, no significant association was observed on multivariate model analysis.

In this study, based on bivariate analysis, there was no significant association between age group and blood pressure control. This result is in contrast to a study by Gu et al. [19] indicating a significant association between the two variables. A study by Zhao et al. [20] also showed that subjects aged 60 years and above showed more awareness in controlling blood pressure. This study showed that the proportion of subjects aged 60 years and above with uncontrolled blood pressure (89\%) was greater than in the age group 50-59 years with uncontrolled blood pressure (85.8\%). This result was similar to that of another study by Borzecki et al., [21] indicating that subjects aged 80 years and above had worse blood pressure control compared with subjects aged 40-59 years. The difference between our results and those of Gu et al., [19] and Zhao et al., [20] is likely attributable to the higher medication adherence of the patients in those studies, which is in contrast to the adherence levels of the patients in the present study, whereby $55.3 \%$ were nonadherent.

In the bivariate analysis, the association between socioeconomic factors (highest educational level achieved and monthly income bracket) and blood pressure control was insignificant. This result was in contrast to the results of a study by Paulsen et al. [22], which showed that there was a significant association between socioeconomic status and blood pressure control. A systematic review by Leng et al. [23] also showed there was a significant association between socioeconomic status and blood pressure control. However, for both the aforementioned studies [22, 23], the study subjects were from developed countries. In contrast, our results are supported by those of Satoh et al. [24], which indicated that there was a significant association between socioeconomic status and the prevalence of hypertension, but there was no significant association between socioeconomic status and blood pressure control in hypertensive patients.

The present study showed there was a significant association between comorbidities and blood pressure control. A clinical review by Schmieder and Ruilope [25] indicated that it was difficult for hypertensive patients with comorbidities to achieve their target blood pressures. Similarly, in our study, the proportion of hypertensive patients with comorbidities with controlled blood pressure was 35.7\%. Similar results were also reported by Paulsen et al., [26], which showed that the proportion of hypertensive patients with comorbidities who were able to achieve their target blood pressures was $33.2 \%$.

In our study, the percentage of hypertensive patients that adhered to their antihypertensive medication treatment was 44.7\%. This value was higher than that reported in the study by Rahmawati and Bajorek [27], which showed an $11 \%$ medication adherence rate. Of the adherent patients, only $24 \%$ achieved their blood pressure targets. This percentage was similar to the value of $25 \%$ reported by Hussain et al. [9], but was lower than the percentages reported by Gu et al. 
[19] and Piercefield et al. [28], who reported controlled blood pressure rates of $44 \%$ and $67.4 \%$, respectively. In the present study, medication adherence was significantly associated with blood pressure control. This result was supported by the study by Gu et al. [19]. Although the proportion of adherent patients with uncontrolled blood pressure was high (76.5\%), it was still lower than the proportion of non-adherent patients (98.3\%). According to the National Stroke Association, adherence is defined as the act of routinely refilling prescriptions on time, while the definition of compliance is the act of routinely taking the prescribed drugs [29]. As the level of compliance was not recorded in this study, this could explain the higher proportion of uncontrolled blood pressure in adherent patients.

There was a significant association between location/setting of detection/diagnosis and blood pressure control. This may be explained by the level of medication adherence in our patients. Of the hypertensive patients who were diagnosed during home visits, $27.2 \%$ were adherent with their antihypertensive medications and had routine clinical visits outside the Tegal Alur II Community Health Center. That proportion was significantly lower than the proportion of hypertensive subjects diagnosed at the Tegal Alur II Community Health Center and who were adherent with their antihypertensive medication $(99.4 \%)$.

The presence of comorbidities was the strongest predictor of blood pressure control in this study. This result was supported by Sarkar [30] who also showed that comorbidities were one of the strongest predictors of blood pressure control in a multivariate analysis, in addition to antihypertensive drugs, age, sex, and ethnicity.

From our clinical experience, the low adherence rate and low blood pressure target achievement are due to lower educational levels. Most of our patients are not aware that hypertension may exist even in the absence of symptoms and thus choose to neglect the disease and not adhere to the physician's recommendation. Due to cultural beliefs, patients may choose to visit non-medical service providers that present alternative choices of treatment. Furthermore, they are also reluctant to weekly visits to our Community Health Center to receive antihypertensive prescriptions. Our Community Health Center also offers a non-pharmacological program for patients with hypertension consisting of bimonthly aerobic training and group discussions. However, only two or three patients attended these activities. This could be a long-standing challenge for our country's battle against hypertension.

\subsection{Determinants of Hypertension in the Tegal Alur Administrative Village}

In this study, bivariate analysis showed that physical activity, smoking habits, and comorbidities were not significantly associated with hypertension. A study by Huai et al. [31] also showed that there was no significant association between physical activity and hypertension. Our results are also supported by studies by Li et al. [32] and Thuy et al. [33] showing the absence of a significant association between smoking habits and hypertension. However, our results contradict those of a case-control study by Pilakkadavath [34], which reported a significant association between comorbidities and hypertension. To our knowledge, there have been no studies to date describing comorbidities with results similar to those of our study.

The only significant determinant of hypertension in this study was BMI; similar results were reported by Wang [35], who showed that BMI had a significant association with hypertension. Furthermore, a prospective cohort study by Okumura [36], which reported that obesity could increase the incidence of hypertension, also supports our results. A linear relationship between BMI and blood pressure was also described in an Indonesian population by Tuan [37].

\subsection{Health-related Quality of Life}

The results from the present study indicate there was a significant difference between hypertensive and normotensive groups in the PF dimension of Health-Related Quality of Life (HRQoL) $(p=0.042)$. The mean value of the PF dimension in the normotensive group was higher than that of the hypertensive group. There was an insignificant difference between the two groups in the other HRQoL dimensions, but the mean value of each dimension was higher in the normotensive group, which was similar to the findings of Trevisol et al. [38].

In the linear regression model, hypertension was still significantly associated with the PF dimension. This result is supported by the study of Wang et al. [39], which showed that hypertension had a significant association with the PF dimension. These results suggest that hypertension affects the daily routines of hypertensive patients.

We found that hypertension had an insignificant association with bodily pain ( $\mathrm{P}$ dimension). Hypertension is a silent disease, which could explain the lack of a significant association between hypertension and bodily pain [39]. We also showed the absence of a significant association between hypertension and emotions, which is consistent with the findings reported by $\mathrm{Xu}$ et al. [6]. 
In the linear regression model, the highest educational level achieved and income bracket were significantly associated with the RP dimension, a result also supported by Xu et al., [6]. In our study, marital status had a significant association with the RP and EF dimensions, which was also reported by Carvalho et al., [7]. Comorbidities were significantly associated with the PF and RE dimensions, which is consistent with the results of a study by Wang et al., [39].

In this study, we utilized a home visit approach to eliminate the possibility of white-coat-induced hypertension. However, no instrument was used to record the compliance of the hypertensive patients. In addition, the majority of patients visited various health care providers aside from the Tegal Alur II Community Health Center. Thus, the authors were not able to verify the true adherence to treatment by hypertensive patients.

\section{CONCLUSION}

The prevalence of hypertension in this study was high, with nearly two of ten adults in the Tegal Alur Administrative Village being affected. The uncontrolled blood pressure rate in this study was higher than that in highincome countries. Medication adherence in this study was lower than that in developed countries. Comorbidities were the strongest predictor of blood pressure control, and there was a significant association between BMI and hypertension.

\section{FUNDING STATEMENT}

This study received no specific grant from any funding agency in the public, commercial, or not-for-profit sectors.

\section{ETHICS APPROVAL AND CONSENT TO PARTICIPATE}

Ethical approval was issued by the Health Research Ethics Committee, Faculty of Medicine, Universitas Indonesia Cipto Mangunkusumo Hospital.

\section{HUMAN AND ANIMAL RIGHTS}

No animals were used in this study. All research procedures followed the ethical standards of the committee responsible for human experimentation and the Helsinki Declaration of 1975 (http://www.wma.net/en/20activities/ 10ethics/10helsinki/).

\section{CONSENT FOR PUBLICATION}

All subjects provided their informed consent to participate in the study.

\section{CONFLICT OF INTEREST}

The authors declare no conflict of interest, financial or otherwise.

\section{ACKNOWLEDGEMENTS}

We appreciate the assistance of Rismauli Aruan, M.D., Head of the Tegal Alur II Community Health Center, and Ranni Asrul, M.D., staff physician at the Tegal Alur II .

\section{REFERENCES}

[1] World Health Organization. A global brief on hypertension 2013. Available from: http://www.who.int/cardiovascular_diseases/publications/ global_brief_hypertension/en/

[2] Krishnan A, Garg R, Kahandallyanage A. Hypertension in the South-East Asia region: An overview. Reg Health Forum 2013 ; $17(1)$ : 7-14. Available from: http://www.searo.who.int/publications/journals/regional_health_forum/rhfv17n1p7.pdf

[3] Kementerian KRI. Riset kesehatan dasar. Jakarta: Kemenkes 2013. Available from: http://www.depkes.go.id/resources/download/general/ Hasil\%20Riskesdas\%202013.pdf

[4] World Health Organization. Global status report on noncommunicable diseases 2014. Available from: http://www.who.int/nmh/publications/ ncd-status-report-2014/en/

[5] Rahajeng E, Tuminah S. Prevalence of hypertension and its determinants in Indonesia 2009. Available from: http://www.academia.edu/ 21468378/Prevalensi_Hipertensi_dan_Determinannya_di_Indonesia

[6] Xu X, Rao Y, Shi Z, Liu L, Chen C, Zhao Y. Hypertension impact on health-related quality of life: A cross-sectional survey among middleaged adults in Chongqing, China 2016. Available from: https://www.hindawi.com/journals/ijhy/2016/7404957/

[7] Carvalho MVD, Siqueira LB, Sousa ALL, Jardim PC. The influence of hypertension on quality of life. Arq Bras Cardiol 2013; 100(2): 
164-74. Available from: http://www.scielo.br/scielo.php?script=sci_arttext\&pid=S0066-782X2013000200009\&lng=en\&nrm=iso\&tlng=en [http://dx.doi.org/10.5935/abc.20130030] [PMID: 23503826]

[8] Cois A, Ehrlich R. Analysing the socioeconomic determinants of hypertension in South Africa: A structural equation modelling approach. BMC Public Health 2014; 14: 414. Available from: https://bmcpublichealth.biomedcentral.com/track/pdf/10.1186/1471-245814-414? site= bmcpublichealth.biomedcentral.com [http://dx.doi.org/10.1186/1471-2458-14-414] [PMID: 24885860]

[9] Hussain MA, Mamun AA, Reid C, Huxley RR. Prevalence, awareness, treatment, and control of hypertension in Indonesian adults aged $>40$ years: Findings from the Indonesia Family Life Survey (IFLS). PloS ONE 2016. Available from: https://www.ncbi.nlm.nih.gov/pmc/articles/ PMC4996427/pdf/pone.0160922.pdf

[10] Menanga A, Edie S, Nkoke C, et al. Factors associated with blood pressure control amongst adults with hypertension in Yaounde, Cameroon: A cross-sectional study. Cardiovasc Diagn Ther 2016; 6(5): 439-45. Available from: https://www.ncbi.nlm.nih.gov/pmc/articles/ PMC5059397/

[http://dx.doi.org/10.21037/cdt.2016.04.03] [PMID: 27747167]

[11] Chobanian AV, Bakris GL, Black HR, et al. The seventh report of the Joint National Committee on prevention, detection, evaluation, and treatment of high blood pressure. JAMA 2003; 289(19): 2560-72. Available from: https://jamanetwork.com/journals/jama/fullarticle/ 10.1001/jama.289.19.2560

[http://dx.doi.org/10.1001/jama.289.19.2560] [PMID: 12748199]

[12] Posnenkova OM, Gerasimov SN, Popova YV, Popov IA, Shemetova GN, Gridnev VI, et al. Clinical factors affecting the goal blood pressure in hypertensive patients of a rural polyclinic in Russia. Open Hypertens J 2017; 9: 6-15. Available from: https:/benthamopen.com/ FULLTEXT/TOHYPERJ-9-6

[http://dx.doi.org/10.2174/1876526201709010006]

[13] Pimenta E. Hypertension in women. Hypertens Res 2012; 35(2): 148-52. Available from: https:/www.nature.com/ articles/hr2011190 [http://dx.doi.org/10.1038/hr.2011.190] [PMID: 22129517]

[14] Ahmad A, Oparil S. Hypertension in women: Recent advances and lingering questions. Hypertension 2017; 70(1): 19-26. Available from: http://hyper.ahajournals.org/content/early/ 2017/05/08/HYPERTENSIONAHA.117.0831

[http://dx.doi.org/10.1161/HYPERTENSIONAHA.117.08317] [PMID: 28483918]

[15] Gudmundsdottir H, Høieggen A, Stenehjem A, Waldum B, Os I. Hypertension in women: Latest findings and clinical implications. Ther Adv Chronic Dis 2012; 3(3): 137-46. Available from: https://www.ncbi.nlm.nih.gov/pmc/ articles/PMC3513905/ [http://dx.doi.org/10.1177/2040622312438935] [PMID: 23251774]

[16] Hanus KM, Prejbisz A, Gąsowski J, et al. Relationship between gender and clinical characteristics, associated factors, and hypertension treatment in patients with resistant hypertension. Kardiol Pol 2017; 75(5): 421-31. Available from: https://ojs.kardiologiapolska.pl/kp/article/view/10909 [http://dx.doi.org/10.5603/KP.a2017.0020] [PMID: 28150289]

[17] Keyhani S, Scobie JV, Hebert PL, McLaughlin MA. Gender disparities in blood pressure control and cardiovascular care in a national sample of ambulatory care visits. Hypertension 2008; 51(4): 1149-55. Available from: http://hyper.ahajournals.org/content/51/4/1149.short [http://dx.doi.org/10.1161/HYPERTENSIONAHA.107.107342] [PMID: 18259013]

[18] Souza CSD, Stein AT, Bastos GAN, Pellanda LC. Blood pressure control in hypertensive patients in the "Hiperdia Program": A territorybased study. Arq Bras Cardiol 2014; 102(6): 571-8. Available from: https://www.ncbi.nlm.nih.gov/pmc/articles/PMC4079021/ pdf/abc-102-06-0571.pdf [PMID: 25004419]

[19] Gu A, Yue Y, Argulian E. Age differences in treatment and control of hypertension in US physician offices, 2003-2010: A serial crosssectional study. Am J Med 2016; 129(1): 50-58.e4. Available from: http://www.amjmed.com/article/S0002-9343(15)00767-6/fulltext [http://dx.doi.org/10.1016/j.amjmed.2015.07.031] [PMID: 26299315]

[20] Zhao Y, Yan H, Marshall RJ, et al. Trends in population blood pressure and prevalence, awareness, treatment, and control of hypertension among middle-aged and older adults in a rural area of Northwest China from 1982 to 2010. PLoS One 2013; 8(4): e61779. Available from: http://journals.plos.org/plosone/article/file?id=10.1371/journal.pone.0061779\&type=printable [http://dx.doi.org/10.1371/journal.pone.0061779] [PMID: 23613932]

[21] Borzecki AM, Glickman ME, Kader B, Berlowitz DR. The effect of age on hypertension control and management. Am J Hypertens 2006; 19(5): 520-7. Available from: https://www.ncbi.nlm.nih.gov/pubmed/16647627 [http://dx.doi.org/10.1016/j.amjhyper.2005.10.022] [PMID: 16647627]

[22] Paulsen MS, Andersen M, Munck AP, et al. Socio-economic status influences blood pressure control despite equal access to care. Fam Pract 2012; 29(5): 503-10. Available from: https://academic.oup.com/fampra/article/29/5/503/553904 [http://dx.doi.org/10.1093/fampra/cmr130] [PMID: 22234552]

[23] Leng B, Jin Y, Li G, Chen L, Jin N. Socioeconomic status and hypertension: A meta-analysis. J Hypertens 2015; 33(2): 221-9. Available from: https://insights.ovid.com/pubmed?pmid=25479029 [http://dx.doi.org/10.1097/HJH.0000000000000428] [PMID: 25479029]

[24] Satoh A, Arima H, Ohkubo T, et al. Associations of socioeconomic status with prevalence, awareness, treatment, and control of hypertension in a general Japanese population: NIPPON DATA2010. J Hypertens 2017; 35(2): 401-8. [http://dx.doi.org/10.1097/HJH.0000000000001169] [PMID: 28005709] 
[25] Schmieder RE, Ruilope LM. Blood pressure control in patients with comorbidities. J Clin Hypertens (Greenwich) 2008 ; 10(8): 624-31. Available from: http://onlinelibrary.wiley.com/doi/10.1111/j.1751-7176.2008.08172.x/epdf [http://dx.doi.org/10.1111/j.1751-7176.2008.08172.x] [PMID: 18772645]

[26] Paulsen MS, Andersen M, Thomsen JL, et al. Multimorbidity and blood pressure control in 37651 hypertensive patients from Danish general practice. J Am Heart Assoc 2012; 2(1): e004531. Available from: http://jaha.ahajournals.org/content/2/1/e004531.long [http://dx.doi.org/10.1161/JAHA.112.004531] [PMID: 23525411]

[27] Rahmawati R, Bajorek B. Factors affecting self-reported medication adherence and hypertension knowledge: A cross-sectional study in rural villages, Yogyakarta Province, Indonesia. Chronic Illn 2017; 0(0): 1742395317739092. Available from: http://journals.sagepub.com/ doi/abs/10.1177/1742395317739092

[PMID: 29119817]

[28] Piercefield EW, Howard ME, Robinson MH, Kirk CE, Ragan AP, Reese SD. Antihypertensive medication adherence and blood pressure control among central Alabama veterans. J Clin Hypertens (Greenwich) 2017; 19(5): 543-9. Available from: http://onlinelibrary.wiley.com/ doi/10.1111/jch.12953/epdf [http://dx.doi.org/10.1111/jch.12953] [PMID: 27917605]

[29] National Stroke Association. Medication adherence and compliance 2012. Available from: https://www.stroke.org/sites/default/files/ resources/NSA_Med_Adherence_brochure.pdf

[30] Sarkar C, Dodhia H, Crompton J, et al. Hypertension: A cross-sectional study of the role of multimorbidity in blood pressure control. BMC Fam Pract 2015; 16: 98. Available from: https://bmcfampract.biomedcentral.com/articles/10.1186/s12875-015-0313-y [http://dx.doi.org/10.1186/s12875-015-0313-y] [PMID: 26248616]

[31] Huai P, Xun H, Reilly KH, Wang Y, Ma W, Xi B. Physical activity and risk of hypertension: A meta-analysis of prospective cohort studies. Hypertension 2013; 62(6): 1021-6. Available from: http://hyper.ahajournals.org/content/early/2013/09/30/HYPERTENSIONAHA.113.01965 [http://dx.doi.org/10.1161/HYPERTENSIONAHA.113.01965] [PMID: 24082054]

[32] Li G, Wang H, Wang K, et al. The association between smoking and blood pressure in men: A cross-sectional study. BMC Public Health 2017; 17(1): 797. Available from: https:/www.ncbi.nlm.nih.gov/pmc/articles/PMC5634904/ [http://dx.doi.org/10.1186/s12889-017-4802-x] [PMID: 29017534]

[33] Thuy AB, Blizzard L, Schmidt MD, Luc PH, Granger RH, Dwyer T. The association between smoking and hypertension in a populationbased sample of Vietnamese men. J Hypertens 2010; 28(2): 245-50. Available from: https://www.ncbi.nlm.nih.gov/pubmed/19829145 [http://dx.doi.org/10.1097/HJH.0b013e32833310e0] [PMID: 19829145]

[34] Pilakkadavath Z, Shaffi M. Modifiable risk factors of hypertension: A hospital-based case-control study from Kerala, India. J Family Med Prim Care 2016; 5(1): 114-9. Available from: https://www.ncbi.nlm.nih.gov/pmc/articles/PMC3746062/ [http://dx.doi.org/10.4103/2249-4863.184634] [PMID: 27453854]

[35] Wang SK, Ma W, Wang S, Yi XR, Jia HY, Xue F. Obesity and its relationship with hypertension among adults 50 years and older in Jinan, China. PLoS One 2014; 9(12): e114424. Available from: http://journals.plos.org/plosone/article?id=10.1371/journal.pone.0114424 [http://dx.doi.org/10.1371/journal.pone.0114424] [PMID: 25517735]

[36] Okumura N, Kondo T, Mastsushita K, et al. Body mass index and the incident hypertension in a long-term prospective cohort of young and middle age Japanese males. Eur Heart J 2013; 34(1): 5965. Available from: https://academic.oup.com/eurheartj/article/34/suppl_1/ $5956 / 2863633$

[37] Nguyen TT, Adair LS, Suchindran CM, He K, Popkin BM. The association between body mass index and hypertension is different between East and Southeast Asians. Am J Clin Nutr 2009; 89(6): 1905-12. Available from: http://ajcn.nutrition.org/content/89/6/1905.full.pdf+html [http://dx.doi.org/10.3945/ajcn.2008.26809] [PMID: 19369374]

[38] Trevisol DJ, Moreira LB, Fuchs FD, Fuchs SC. Health-related quality of life is worse in individuals with hypertension under drug treatment: Results of population-based study. J Hum Hypertens 2012; 26(6): 374-80. Available from: https://www.nature.com/articles/jhh201148.pdf [http://dx.doi.org/10.1038/jhh.2011.48] [PMID: 21593782]

[39] Wang R, Zhao Y, He X, et al. Impact of hypertension on health-related quality of life in a population-based study in Shanghai, China. Public Health 2009; 123(8): 534-9. Available from: http://www.publichealthjrnl.com/article/S0033-3506(09)00166-8/fulltext [http://dx.doi.org/10.1016/j.puhe.2009.06.009] [PMID: 19665154]

(C) 2018 Bawazir and Sianipar.

This is an open access article distributed under the terms of the Creative Commons Attribution 4.0 International Public License (CC-BY 4.0), a copy of which is available at: (https://creativecommons.org/licenses/by/4.0/legalcode). This license permits unrestricted use, distribution, and reproduction in any medium, provided the original author and source are credited. 